\title{
TINJAUAN YURIDIS TENTANG PERATURAN PERLINDUNGAN HUKUM BAGI PELAUT AKIBAT PEMUTUSAN HUBUNGAN KERJA SEPIHAK
}

\author{
Meinina $^{1^{*}}$, Fakhrurrozi $^{1}$ \\ ${ }^{1}$ Program studi Nautika, Politeknik Bumi Akpelni \\ Jl. Pawayatan Luhur II/17, Bendan Dhuwur, Semarang. \\ *Email: meinina.sugiarto@yahoo.com
}

\begin{abstract}
Abstrak
Kajian tentang aspek perlindungan hukum bagi pelaut di kapal Indonesia, berdasarkan ketentuan peraturan perundang-undangan yang berlaku, merupakan suatu kajian yang menarik untuk dibahas dan dipelajari. Baik mengenai ketentuan peraturannya ataupun bentuk rekonstruksi perlindungan hukumnya, khususnya apabila terjadi kasus pemutusan hubungan kerja sepihak dari pengusaha kapal. Penelitian ini didasarkan pada penelitian yuridis normatif, dengan mendasarkan hasil penelitian pada data primer Putusan Pengadilan Nomor 215/Pdt.Sus-PHI/2018/PN Jkt.Pst. Ruang lingkup permasalahan membahas mengenai aspek yuridis dalam peraturan perundang-undangan di Indonesia dalam memberikan perlindungan hukum bagi ABK dan ketentuan peraturan perundang-undangan dalam memberikan perlindungan hukum bagi ABK akibat pemutusan hubungan kerja sepihak oleh pengusaha kapal. Hal ini mengingat bahwa perlindungan hukum bagi pelaut berdasarkan ketentuan dalam UU No. 15 Tahun 2015 tentang Ratifikasi MLC 2006 dan UU No. 13 Tahun 2003 tentang Ketenagakerjaan dan PP No. 7 Tahun 2000 tentang Kepelautan, belum sepenuhnya dapat dilaksanakan, dan masih adanya kasus-kasus mengenai pemutusan hubungan kerja sepihak yang di lakukan oleh pengusaha kapal tanpa didasarkan pada suatu alasan yang dapat diterima berdasarkan ketentuan peraturan yang berlaku.
\end{abstract}

Kata kunci: Perlindungan Hukum, Pelaut, Pemutusan Hubungan Kerja

\section{PENDAHULUAN}

Moda transportasi memiliki peran yang penting sebagai sarana penunjang ketercapaian dari pembangunan ekonomi nasional disuatu negara. Pada prinsipnya ketergantungan hubungan antara peningkatan dalam kegiatan ekonomi dan industri dengan kebutuhan menyeluruh akan tersedianya sarana angkutan, dengan kata lain dapat dijelaskan jika aktivitas ekonomi meningkat maka kebutuhan akan angkutan juga akan meningkat. Dalam industri maritim sendiri, kapal laut menjadi moda transportasi yang banyak diminati oleh para eksportir maupun pemilik barang, sebagai sarana angkutan pengiriman barang ke tempat tujuan. Untuk dapat memberikan pelayanan transportasi yang selamat dan aman, setiap perusahaan pelayaran dituntut untuk menyediakan sarana angkutan atau kapal yang selalu dalam kondisi laik laut, dan diawaki oleh pelaut-pelaut yang kompeten dan memiliki kecakapan pelaut yang baik. Kondisi lingkungan kerja yang baik dan memenuhi standar keselamatan baik nasional maupun internasional, menjadi perhatian Kementerian Perhubungan melalui Direktorat Jenderal Perhubungan Laut untuk terus ditingkatkan. Untuk itu perlu adanya perlindungan dan penegakan hukum dalam bidang transportasi. Penegakan hukum yang dimaksud adalah soal perlindungan kerja yang meliputi tiga aspek, yakni aspek kesejahteraan, aspek keselamatan kerja dan aspek kesehatan kerja, sebagaimana ketentuan Pasal 35 ayat (1) Peraturan Pemerintah Nomor 51 Tahun 2012 tentang Sumber Daya Manusia di Bidang Transportasi.

Berbicara mengenai perlindungan hukum bagi para pelaut, salah satu unsurnya adalah pengawasan yang baik dan penindakan tegas apabila terjadi pelanggaran oleh aparat penegak hukum. Pasal 41 ayat (1) PP No. 51 Tahun 2012 menyatakan menteri (dalam hal ini menteri perhubungan) dan menteri yang menyelenggarakan urusan 
pemerintahan di bidang ketenagakerjaan, untuk ikut serta melakukan pengawasan terhadap pelaksanaan perlindungan kerja yang dilakukan oleh pemberi kerja sebagaimana dimaksud dalam Pasal 35 peraturan ini. Sebagai wujud nyata dari upaya memberikan perlindungan terhadap para pelaut, pemerintah telah meratifikasi Maritime Labour Convention (MLC) 2006 dengan Undang-Undang No. 15 Tahun 2016 tentang Pengesahan MLC 2006 Sebagai Undang-Undang Perburuhan Maritim Di Indonesia.

Kurangnya pemahaman pelaut terhadap aspek perlindungan hukum yang terdapat dalam PKL, menjadikan pelaut menurut saja atas apa yang menjadi kebijakan perusahaan. Kejadian yang dialami oleh saudara AFSP sebagai pelaut yang bekerja di PT KLS merupakan salah satu dari sekian banyak ketidakadilan yang dialami oleh pelaut akibat pemutusan hubungan kerja sepihak. Dalam hal ini seharusnya klausul mengenai penyelesaian sengketa atau adanya wanprestasi, baik yang dilakukan oleh pengusaha kapal maupun oleh pelaut harusnya juga dimunculkan dalam PKL. Sehingga kejadian seperti pemutusan hubungan kerja sepihak, ataupun penetapan kebijakan sepihak dari Nakhoda selaku wakil perusahaan ataupun pihak pemilik kapal, tidak perlu lagi terjadi. Tujuan dari penelitian ini adalah untuk mengetahui dan menganalisis mengenai aspek yuridis dalam peraturan perundangundangan di Indonesia dalam memberikan perlindungan hukum bagi $\mathrm{ABK}$ dan mengetahui dan menganalisis mengenai ketentuan peraturan perundang-undangan dalam memberikan perlindungan hukum bagi ABK akibat pemutusan hubungan kerja sepihak oleh pengusaha kapal.

\section{LANDASAN TEORI}

Pengertian perlindungan hukum menurut Soerjono Soekanto (2007) merupakan segala upaya pemenuhan hak dan pemberian bantuan untuk memberikan rasa aman kepada saksi dan atau korban, yang dapat diwujudkan dalam bentuk seperti melalui restitusi, kompensasi, pelayanan medis, dan bantuan hukum. Soekanto menjelaskan bahwa perlindungan hukum ini akan memberikan hak keamanan dan keselamatan, termasuk informasi-informasi yang benar, jelas dan jujur mengenai kondisi dan jaminan atas dirinya, saksi dan korban untuk setiap upaya penyelesaian permasalahan yang muncul. Wujud dari peran hukum dalam masyarakat adalah memberikan perlindungan hukum kepada anggota masyarakat yang kepentingannya terganggu. Persengketaan yang terjadi dalam masyarakat harus diselesaikan menurut hukum yang berlaku, sehingga dapat mencegah perilaku main hakim sendiri. Tujuan pokok hukum sebagai perlindungan kepentingan manusia adalah menciptakan tatanan masyarakat yang tertib, sehingga terwujud kehidupan yang seimbang.

Menurut Undang-Undang No. 15 Tahun 2016, tentang Ratifikasi MLC 2006, sebagai peraturan perundang-undangan maritim di Indonesia, sebagaimana yang tertulis dalam Seafarer's Bill of Rights an ITF (2006), mengharuskan setiap perusahaan pemilik kapal (ship owner), untuk dapat memenuhi hak para pelaut yang dipekerjakan dikapalnya sebagai wujud nyata dalam upaya peningkatan kesejahteraan pelaut, diantaranya keselamatan, keamanan dan kesejahteraan pada saat melaksanakan kerja selama berdinas di kapal, memperoleh syarat perjanjian kerja yang wajar sesuai dengan ketentuan perundang-undangan, mendapatkan kenyamanan tempat kerja, fasilitas rekreasi atau hiburan dan pelayanan makanan, serta perlindungan dan perawatan kesehatan, kesejahteraan terhadap perlindungan sosial.

Menurut Engkos Kosasih (2007) Anak Buah Kapal adalah para pelaut yang bekerja di kapal setelah memenuhi persyaratan administratif pengawakan kapal yaitu, melakukan Perjanjian Kerja Laut (PKL), terdaftar dalam buku sijil awak kapal, dan memenuhi persyaratan yang ditetapkan dalam hukum perkapalan. ABK yang siap 
bekerja di kapal harus memiliki persyaratan khusus yaitu, sertifikat kesehatan, buku pelaut, paspor (bagi pelaut yang ke luar negeri), ijasah atau sertifikat kompetensi, sertifikat proficiensi dan surat kontrak. Dalam dunia kerja, kita lazim mendengar istilah Pemutusan Hubungan Kerja atau yang sering disingkat dengan kata PHK. Apa pun penyebab berakhirnya hubungan kerja antara perusahaan dan karyawannya disebut dengan PHK. PHK sering kali menimbulkan keresahan khususnya bagi para pekerja. Hal ini dikarenakan keputusan PHK ini akan berdampak buruk bagi kelangsungan hidup dan masa depan para pekerja yang mengalaminya. Pemutusan Hubungan Kerja (PHK) menurut Aldiyansah (2008) adalah pengakhiran hubungan kerja karena suatu hal tertentu yang mengakibatkan berakhirnya hak dan kewajiban antara pekerja dan perusahaan/ majikan. Hal ini dapat terjadi karena pengunduran diri, pemberhentian oleh perusahaan atau habis kontrak.

\section{METODE}

Penelitian ini dilakukan untuk mengidentifikasi dan membandingkan antara kesenjangan dalam peristiwa hukum (das Sein) dengan aturan hukum (das Sollen), antara aturan khusus (lex specialis) dengan aturan yang lebih umum (lex generalis). Metode berpikir yang digunakan adalah metode berpikir deduktif. Dalam metode deduktif ini merupakan cara berpikir dalam penarikan kesimpulan yang ditarik dari sesuatu yang sifatnya umum yang sudah dibuktikan bahwa dia benar dan kesimpulan itu ditujukan untuk sesuatu yang sifatnya khusus.

Penelitian data atau studi kepustakaan merupakan salah satu teknik pengumpulan data untuk mendapatkan data yang bersifat sekunder, yaitu data yang berasal dari literatur-literatur buku-buku, pendapat para sarjana yang membidangi hukum pelayaran. Dalam penelitian ini mengkaji mengenai putusan Pengadilan Negeri Jakarta Pusat Nomor 215/Pdt.Sus-PHI/2018/PN Jkt.Pst.
Data yang telah terkumpul, baik data primer maupun data sekunder kemudian disajikan dalam bentuk uraian peristiwa atau kalimat yang mudah dipahami. Proses pengolahan data yang dilakukan adalah dengan memeriksa, meneliti data yang diperoleh untuk menjamin apakah data dapat dipertanggungjawabkan sesuai dengan kenyataan, melalui proses editing. Analisis data adalah proses menyusun data agar data tersebut dapat ditafsirkan. Analisis merupakan proses penyederhanaan kata ke dalam bentuk yang lebih mudah dibaca dan diinterpretasikan. Dalam hal ini, analisis yang digunakan adalah analisis data kualitatif.

\section{HASIL DAN PEMBAHASAN \\ Aspek Yuridis Dalam Peraturan Perundang-Undangan Di Indonesia Dalam Memberikan Perlindungan Hukum Bagi ABK.}

Pemerintah memiliki kewajiban untuk dapat menjaga ketentuan dalam peraturan perundang-undangan sebagai aspek dalam memberikan perlindungan hukum kepada seluruh masyarakat. Perlu dipahami bahwa Substansi hukum menurut Friedman (1984:5-6) adalah "Another aspect of the legal system is its substance. By this is meant the actual rules, norm, and behavioral patterns of people inside the system ...the stress here is on living law, not just rules in law books".

Sebagai operator di kapal, awak kapal memegang peran yang sangat penting untuk terselenggaranya layanan jasa transportasi laut yang aman, efisien dan ramah lingkungan dengan mengutamakan prinsip keselamatan. Agar awak kapal dapat menjalankan tugas dengan baik, tentu saja harus didukung dengan situasi dan kondisi kerja yang kondusif. Untuk itu sangat diperlukan kehadiran pemerintah dalam hal pengawasan, terhadap pemberlakuan konvensi ketenagakerjaan maritim, 2006 ini. Dijelaskan dalam aturan penjelasan mengenai UU No. 15 Tahun 2016, bahwa setiap negara anggota wajib memberlakukan secara penuh ketentuan- 
ketentuan dalam Konvensi Ketenagakerjaan Maritim, 2006. Negara anggota wajib saling bekerja sama dengan maksud untuk memastikan pelaksanaan dan penegakan Maritime Labour Convention, 2006 (Konvensi Ketenagakerjaan Maritim, 2006) ini secara efektif. Aspek perlindungan hukum bagi ABK dituangkan dalam bentuk Peraturan dan Koda yang terdiri dari 3 (tiga bagian yaitu Articles/ Pasal-Pasal, Regulation/ Peraturan dan Codel Koda. Pasal-pasal dan peraturan menetapkan hakhak dan prinsip-prinsip dasar dan kewajiban-kewajiban dasar Negara Anggota Organisasi Ketenagakerjaan Internasional yang meratifikasi Maritime Labour Convention, (MLC) 2006 (Konvensi Ketenagakerjaan Maritim, 2006. Sedangkan Code/Koda memuat rincianrincian bagi penerapan peraturan-peraturan. Code/Koda memuat 2 (dua) bagian yaitu Bagian A berisi standar-standar yang sifatnya mandatory/wajib yang harus diterapkan oleh negara yang meratifikasi Konvensi dan Bagian B berisi pedomanpedoman yang sifatnya non-mandatory/ tidak wajib untuk diterapkan oleh negara yang meratifikasi Konvensi.

Peraturan dan Koda dalam UU Ketenagakerjaan Maritim ini, secara detail telah memberikan ketentuan dan persyaratan minimal yang harus dipenuhi oleh perusahaan atau pengusaha kapal, sebelum mempekerjakan seorang ABK di kapal. Ketentuan dan peraturan tersebut mengatur aspek-aspek perlindungan hukum dalam hal:

a. ketentuan minimum bagi para pelaut untuk bekerja di kapal;

b. kondisi lingkungan kerja;

c. akomodasi, fasilitas-fasilitas rekreasi, makanan dan katering;

d. perlindungan kesehatan, perawatan medik, kesejahteraan dan jaminan sosial;

e. kepatuhan dan penegakan.

Lima aspek perlindungan hukum yang dituangkan dalam aturan penjelasan UU No. 15 Tahun 2016 tersebut merupakan ketentuan dan regulasi dari MLC 2006 sebagai UU Ketenagakerjaan Maritim
Internasional. Aspek ketentuan minimum bagi para pelaut untuk dapat bekerja di kapal, mengatur dalam hal:

a. pembatasan usia minimum untuk bekerja di kapal;

b. ketentuan dimilikinya sertifikat kesehatan bagi masing-masing pelaut;

c. adanya pelatihan dan kualifikasi atas kompetensi dan keahlian pelaut yang ditunjukkan dengan kepemilikan sertifikat baik kompetensi atau profesi; dan

d. pemenuhan ketentuan rekruitmen dan prosedure penempatan bagi $\mathrm{ABK}$ di kapal (regulasi/kode 1.4).

Hal ini ditegaskan kembali dalam Peraturan Pemerintah Nomor 7 Tahun 2000 tentang Kepelautan, Pasal 17 yang menjelaskan bahwa, untuk dapat bekerja di kapal maka sebagai awak kapal, wajib memenuhi persyaratan :

a. memiliki sertifikat keahlian pelaut dan/atau sertifikat keterampilan pelaut;

b. berumur sekurang-kurangnya 18 tahun;

c. sehat jasmani dan rohani berdasarkan hasil pemeriksaan kesehatan yang khusus dilakukan untuk itu; dan

d. disijil.

Kondisi lingkungan kerja di kapal merupakan penggambaran dari kesejahteraan bagi ABK yang bekerja di kapal. Kondisi lingkungan kerja berdasarkan ketentuan dalam Regulasi/Kode ke-2 MLC 2006 ini, mengatur tentang kontrak kerja, gaji dan kondisi lingkungan kerja bagi ABK. ILO sebagai organisasi perburuhan internasional ingin memastikan apakah para pelaut atau ABK yang bekerja di kapal telah mendapatkan tempat kerja dan merasakan lingkungan kerja yang baik dan layak di kapal. Tidak hanya itu, ketentuan regulasi atau kode ini juga memberikan jaminan kepada para ABK untuk mendapatkan tempat kerja yang selamat dan aman. Dalam aspek ini meliputi perlindungan yang tertuang dalam Perjanjian Kerja Laut (regulasi/kode 2.1), pemberian gaji atau upah kerja (regulasi/kode 2.2), kebijakan mengenai jam kerja dan jam istirahat 
(regulasi/kode 2.3), hak atas cuti Pengusaha kapal wajib menuangkan semua (regulasi/kode 2.4), dan kebijakan aspek kesejahteraan bagi ABK sesuai pemulangan selesai kontrak kerja ketentuan dalam Pasal 151 ayat (1) UUP di (regulasi/kode 2.5).

Dalam ketentuan regulasi 3 dari ketentuan MLC 2006 mengatur mengenai aspek perlindungan kepada para pelaut terkait dengan kenyamanan tempat kerja berupa Akomodasi, fasilitas hiburan atau rekreasi di kapal dan pelayanan permakanan dan pelayanan katering di kapal. MLC 2006 dalam ketentuan regulasi/kode 3.1, memberikan ketentuan standar terhadap pemenuhan fasilitas-fasilitas untuk akomodasi dan tempat rekreasi dikapal dengan ketentuan standar, dengan pengaturan dan luas bagian-bagian ruangan yang disesuaikan dengan yang dijelaskan dalam regulasi/kode ini. Perlindungan terhadap jaminan kesehatan, perawatan medis, kesejahteraan dan jaminan social bagi setiap ABK merupakan kewajiban dari pihak perusahaan untuk memenuhinya. Dalam hal ini, Iman Soepomo (1985:139), berpendapat bahwa dalam UU Kecelakaan tidak dengan tegas mencabut dan menggantikan Peraturan kecelakaan (Ongevallen-regeling 1939) dan peraturan pelaksanaannya (Ongevallen-verordening 1939), namun demikian harus diartikan sebagai telah mencabut dan menggantikan Peraturan Kecelakaan 1939 dimaksud.

Aspek perlindungan terhadap kesejahteraan bagi ABK juga dituangkan dalam Pasal 151 ayat (1) UUP di mana setiap awak kapal berhak mendapatkan kesejahteraan yang meliputi:

a. gaji;

b. jam kerja dan jam istirahat;

c. jaminan pemberangkatan ke tempat tujuan dan pemulangan ke tempat asal;

d. kompensasi apabila kapal tidak dapat beroperasi karena mengalami kecelakaan;

e. kesempatan mengembangkan karier;

f. pemberian akomodasi, fasilitas rekreasi, makanan/minuman; dan

g. pemeliharaan dan perawatan kesehatan serta pemberian asuransi kecelakaan kerja. atas ke dalam suatu bentuk Perjanjian Kerja Laut, yang merupakan bentuk kesepakatan bersama antara pihak pengusaha dan pelaut atau sebagai bentuk perjanjian individu yang bersifat khusus.

Bentuk perlindungan yang diberikan juga dituangkan dalam Pasal 310 UU No. 17 Tahun 2008 tentang Pelayaran yang menyatakan bahwa setiap orang yang mempekerjakan Awak Kapal tanpa memenuhi persyaratan kualifikasi dan kompetensi sebagaimana dimaksud dalam Pasal 135, dipidana dengan pidana penjara paling lama 2 (dua) tahun dan denda paling banyak Rp. 300.000.000,00 (tiga ratus juta rupiah). Ketentuan pidana ini menjadi suatu bentuk perlindungan bahwa perusahaan harus memastikan bahwa pelaut yang akan dipekerjakan benar-benar telah memenuhi semua persyaratan kualifikasi, sertifikasi, kompetensi dan memiliki keahlian dibidangnya. Demikian juga yang tertuang dalam Pasal 312 UUP, yaitu setiap orang yang mempekerjakan seseorang di kapal dalam jabatan apa pun tanpa disijil dan tanpa memiliki kompetensi dan keterampilan serta dokumen pelaut yang dipersyaratkan sebagaimana dimaksud dalam Pasal 145 dipidana dengan pidana penjara paling lama 2 (dua) tahun dan denda paling banyak Rp. 300.000.000,00 (tiga ratus juta rupiah). Ini menunjukkan bahwa perjanjian kerja harus dibuat sebelum pelaut tersebut bekerja di kapal, dan pelaut tersebut didaftarkan di pejabat yang berwenang (Syahbandar) dan dicantumkan/ dicatat dalam buku sijil.

Dalam penegakan dan pemenuhan terhadap semua ketentuan mengenai aspek-aspek perlindungan hukum bagi pelaut atau $\mathrm{ABK}$ di kapal berdasarkan ketentuan dalam UU No. 15 Tahun 2016 atau UU No. 17 Tahun 2008 dan PP No. 7 Tahun 2000 ini, menjadi kewajiban utama pemerintah, khususnya pihak syahbandar selaku pengawas dan yang bertanggung jawab terhadap operasional dan keselamatan pelayaran, 
untuk terus memantau dan melakukan pemeriksaan-pemeriksaan secara konsisten erhadap kapal-kapal yang singgah di pelabuhan. Dukungan dan peran serta dari pihak perusahaan dalam memberikan pemenuhan terhadap semua ketentuan tersebut juga merupakan suatu perwujudan bahwa aspek perlindungan hukum yang ditetapkan oleh pemerintah telah dijalankan dan dilaksanakan. Demikian juga, para Nakhoda di kapal dan ABK, untuk dapat melaksanakan semua kewajibannya dan bekerja melaksanakan pekerjaannya sesuai dengan yang disepakati bersama dalam ketentuan Perjanjian Kerja Laut yang telah di tandatangani dan disahkan oleh pihak Syahbandar.

\section{Ketentuan Peraturan Perundang- Undangan Dalam Memberikan Perlindungan Hukum Bagi ABK Akibat Pemutusan Hubungan Kerja Sepihak Oleh Pengusaha Kapal}

Pasal 1 angka 25 UUK memberikan pengertian mengenai definisi Pemutusan Hubungan Kerja sebagai pengakhiran hubungan kerja karena suatu hal tertentu yang mengakibatkan berakhirnya hak dan kewajiban antara pekerja/buruh dan pengusaha. Tidak ada siapapun yang menginginkan terjadinya PHK baik dari pihak pekerja maupun pengusaha, karena dengan PHK tersebut, pekerja/buruh yang bersangkutan akan kehilangan mata pencaharian untuk menghidupi dirinya dan keluarganya. Namun tidak menutup kemungkinan, PHK sewaktu-waktu juga bisa terjadi, seperti PHK karena habisnya masa kontrak kerja yang dikenal dengan PHK yang terjadi demi hukum, PHK karena keinginan pekerja sendiri, PHK oleh Majikan atau pengusaha dan PHK oleh pengadilan. PHK merupakan suatu permasalahan dalam hubungan industrial antara pekerja dan pengusaha.

Dari beberapa macam PHK di atas, yang sering menjadi penyebab timbulnya permasalahan hubungan industrial adalah yang disebabkan karena adanya pemutusan hubungan kerja sepihak dari pengusaha, gaji tidak dibayar, gaji tidak sesuai dengan Perjanjian Kerja Laut (PKL), hingga soal hak Tunjangan Hari Raya (THR) Keagamaan yang tidak diberikan oleh perusahaan. Dari beberapa permasalahan tersebut, pemutusan hubungan kerja sepihat oleh pengusaha merupakan suatu bentuk pelanggaran yang paling banyak memunculkan pengaduan dan permasalahan dalam kasus-kasus hubungan Industrial, karena hal ini tidak sesuai dengan kesepakatan atau perjanjian kerja yang telah dibuat.

Pemutusan hubungan kerja sepihak ini juga kerap terjadi terhadap ABK yang bekerja di kapal, walaupun sebelum bekerja di kapal, sudah dibuat kesepakatan bersama dalam Perjanjian Kerja Laut. Berdasarkan PP No. 7 Tahun 2000 tentang Kepelautan, Pasal 1 ayat (5), Perjanjian Kerja Laut adalah perjanjian kerja perorangan yang ditandatangani oleh pelaut Indonesia dengan pengusaha angkutan di perairan. Bahwa Pasal 18 ayat (4) PP Kepelautan juga mengatur bahwa PKL harus diketahui oleh pejabat Pemerintah yang ditunjuk oleh Menteri. Kemudian, PP Kepelautan, Pasal 15 ayat (2) menyatakan "Bagi pelaut yang telah disijil diberikan buku pelaut". Penjelasan ayat (2) menyatakan buku pelaut merupakan dokumen resmi negara yang dikeluarkan oleh Pemerintah Republik Indonesia yang mencantumkan keterangan lengkap yang sah tentang pribadi dan hubungan kerja dari pemegang buku pelaut dengan pengusaha kapal.

Kesepakatan yang telah dibuat bersama berdasarkan aturan-aturan yang sudah ditetapkan oleh pemerintah Indonesia, seharusnya dapat menghindari adanya pemutusan hubungan kerja sepihak dari para pihak. Namun demikian, ada beberapa alasan yang dapat dibenarkan untuk terjadinya pemutusan hubungan kerja sepihak ini. Ketentuan dalam Pasal 418 KUHD, memberikan alasan mendesak yang dibenarkan, apabila pengusaha kapal melakukan pemutusan hubungan kerja sepihak kepada pelaut. Beberapa alasan tersebut yaitu: 
a. apabila buruh menganiaya Nakhoda atau seorang penumpang kapal, menghinanya dengan kasar, mengancam dengan sungguh-sungguh, membujuk dan mencoba melakukan perbuatan yang bertentangan dengan undang-undang atau kesusilaan;

b. pelaut tidak melapor ke kapal atau tidak datang ke kapal di mana dia dipekerjakan setelah ditandatanganinya PKL;

c. apabila wewenang pelaut karena akibat perbuatan pidana atau keputusan pengadilan sehingga untuk sementara atau untuk selamanya dicabut untuk melakukan dinas dalam jabatan yang untuk itu ia telah mengikatkan diri untuk bekerja; dan

d. apabila tanpa sepengetahuan pengusaha kapal atau Nakhoda, buruh melakukan penyelundupan ke kapal dan menyimpannya di kapal.

Ketentuan mengenai alasan bagi pengusaha untuk memutuskan hubungan kerja juga di jelaskan dalam Pasal 167 UUK. Selain alasan mendesak bagi pengusaha kapal, pelaut sebagai penerima kerja juga memiliki alasan mendesak yang dibenarkan apabila pelaut mengajukan untuk melakukan pemutusan hubungan kerja sepihak. Alasan mendesak bagi pelaut dijelaskan dalam Pasal 419 KUHD juncto Pasal 169 UUK.

a. Bila pengusaha kapal memberi perintah yang bertentangan dengan isi yang ada di dalam perjanjian kerja atau peraturan perundang-undangan;

b. Bila pengusaha kapal menentukan tujuan kapal ke suatu negara yang tersangkut perang laut, atau ke pelabuhan yang diblokir, sedang hal tersebut tidak dituangkan dalam PKL;

c. Bila pengusaha kapal menggunakan kapalnya untuk perdagangan budak, pembajakan, pelayaran pembajakan yang terlarang, atau untuk pengangkutan barang yang pemasukannya dilarang di negara tujuan;

d. Bila pengusaha kapal menggunakan kapalnya untuk pengangkutan barang terlarang, kecuali telah diatur dalam PKL;

e. Adanya ancaman bahwa ia akan dianiaya oleh Nakhoda atau seorang penumpang;

f. Tempat bekerja dan istirahat di kapal mengancam kesehatan bagi pelaut;

g. Bila jatah makan yang menjadi haknya tidak diberikan kepadanya atau tidak diberikan dalam keadaan baik;

h. Bila kapalnya kehilangan hak untuk memakai bendera Indonesia; dan

i. Bila perjanjian kerjanya diadakan untuk satu kali perjalanan tertentu atau lebih, dan pengusaha kapal menyuruh untuk melakukan perjalanan yang lainnya yang tidak sesuai dengan PKL.

Sebagai bentuk perjanjian kerja khusus, maka sudah sepatutnya pengusaha kapal selalu mendasarkan kebijakannya dalam melakukan pemutusan hubungan kerja pada ketentuan dalam Pasal 418 KUHD. Menjadi suatu kewajaran, apabila perusahaan melakukan pemutusan hubungan kerja sepihak di karenakan alasan-alasan mendesak dalam Pasal 418 KUHD tersebut. Namun apabila tidak ada alasan yang mendesak, maka pelaut dapat melakukan tuntutan-tuntutan atas hak-haknya sebagai bentuk perlindungan hukum terhadap dirinya. Berdasarkan ketentuan dalam UU No. 15 Tahun 2016, dimana pemerintah negara anggota mempunyai kewajiban untuk melakukan pengawasan terhadap implementasi ketentuan ketenagakerjaan maritim ini, maka menjadi suatu keharusan untuk dapat memberikan solusi dan perlindungan terhadap pelaut. Sebagaimana yang dialami oleh seorang pelaut AFSP, yang bekerja sebagai Mualim II di kapal M/T KS, milik PT KLS di Jakarta. Atas permasalahan AFSP yang diputus hubungan kerjanya secara sepihak oleh perusahaan, oleh pihak AFSP permasalahan ini kemudian diajukan ke Pengadilan Negeri Jakarta Pusat. Pemerintah sebagai pengawas atas implementasi dari pelaksanaan peraturan, telah memberikan suatu bentuk perlindungan hukum yang cukup baik, melalui keputusan pengadilan No. 215/Pdt.Sus-PHI/2018/PN.Jkt.Pst. 
AFSP adalah pelaut yang dipekerjakan oleh PT KLS sebagai Mualim II di kapal M/T KS berdasarkan pada perjanjian kerja PKL No. PK.309/914/SYB.TPK-17 tertanggal 18 Agustus 2017 untuk jangka waktu 8 (delapan) bulan. PKL yang dibuat oleh kedua belah pihak telah di ketahui dan di tandatangani dihadapan pejabat Syahbandar. Berdasarkan PKL tersebut seharusnya kontrak kerja AFSP berakhir pada tanggal 18 April 2018. Tetapi fakta di lapangan Penggugat diturunkan secara sepihak dengan alasan yang tidak berdasar, lalu dipulangkan ke tanah air dengan biaya pemulangan dibebankan kepada Penggugat yang dipotong dari gajinya dan sampai di Indonesia pada tanggal 11 Oktober 2017. Tanpa adanya suatu alasan mendesak atau suatu bentuk kesalahan yang dilakukan oleh AFSP, tiba-tiba diberhentikan secara sepihak. Sedangkan di dalam PKL yang dibuat oleh AFSP dan PT KLS, berlaku ketentuan yang merujuk pada perjanjian kerja waktu tertentu yaitu 8 (delapan) bulan lamanya. Atas permasalahan ini, AFSP yang juga anggota SP/SB PPI, telah mencoba secara baik melakukan penyelesaian kasusnya dari tingkat bipartit, tripartit dan pada akhirnya mengajukan keberatan dan meminta ganti kerugian atas tindakan pemutusan hubungan sepihak yang di lakukan oleh PT KLS kepada Pengadilan Negeri Jakarta Pusat. Kemudian atas permasalahan tersebut, dalam gelar perkara dan hasil persidangannya, Ketua Majelis Hakim Pengadilan Hubungan Industrial Pada Pengadilan Negeri Kelas 1 A Khusus Jakarta Pusat, pada hari Kamis tanggal 25 Oktober 2018, membacakan hasil putusannya terkait gugatan perkara nomor 215/Pdt.Sus-PHI/2018/PNJkt.Pst, yang diajukan oleh Pergerakan Pelaut Indonesia (PPI) selaku kuasa hukum pelaut Sdr. Ari Friska Sangapta Pinem (Penggugat) terhadap PT. Kawoori Lintas Samudra (KLS) atas pemutusan hubungan kerja yang dilakukan secara sepihak yang terjadi pada 11 Oktober 2017 silam.

Dalam beberapa kali persidangan, ternyata pihak PT KLS selaku tergugat tidak pernah hadir tanpa alasan yang sah, dan atas pertimbangan-pertimbangan yang cukup kuat dan dapat dibuktikan secara sah, maka Majelis Hakim memutuskan bahwa.

a. Menyatakan bahwa Tergugat telah dipanggil dengan sah namun tidak hadir;

b. Mengabulkan gugatan Penggugat untuk sebagian dengan Verstek;

c. Menyatakan putus hubungan kerja antara Penggugat dan Tergugat terhitung sejak 11 Oktober 2017;

d. Menghukum Tergugat untuk membayar kepada Penggugat atas pemutusan hubungan kerja tersebut berupa ganti rugi dan uang pengganti tiket, yang seluruhnya sebesar USD 15.056,- (lima belas ribu lima puluh enam dollar Amerika Serikat);

e. Menolak gugatan Penggugat untuk selain dan selebihnya;dan

f. Membebankan biaya perkara kepada Tergugat sebesar Rp.716.000.- (tujuh ratus enam belas ribu rupiah).

Berdasarkan Putusan Pengadilan tersebut, secara normatif semua dapat dibenarkan, mengingat Penggugat yaitu AFSP tidak melakukan suatu kesalahan atas apa yang diperjanjikan dalam PKL, sedangkan pihak perusahaanlah yang justru terbukti bersalah karena telah melanggar ketentuan yang ada dalam PKL, mengenai masa kontrak kerja bagi AFSP. Pasal 337 UUP telah memberikan suatu rujukan dalam penyelesaian sengketa, dengan merujuk pada UU Ketenagakerjaan. Maka berdasarkan Pasal 62 UUK, apabila salah satu pihak mengakhiri hubungan kerja sebelum berakhirnya jangka waktu yang ditetapkan dalam perjanjian kerja waktu tertentu, atau berakhirnya hubungan kerja bukan karena ketentuan sebagaimana dimaksud dalam Pasal 61 ayat (1) UUK, pihak yang mengakhiri hubungan kerja diwajibkan membayar ganti rugi kepada pihak lainnya sebesar upah pekerja/buruh sampai batas waktu berakhirnya jangka waktu perjanjian kerja. 


\section{KESIMPULAN}

Sebagai pelaut yang setiap hari bekerja di laut, memiliki risiko pekerjaan yang tinggi. Namun demikian belum semua pelaut memperoleh perlindungan hukum terhadap dirinya. Perlindungan hukum bagi pelaut berdasarkan ketentuan dalam UU No. 15 Tahun 2015 tentang Ratifikasi MLC 2006 dan UU No. 13 Tahun 2003 tentang Ketenagakerjaan dan PP No. 7 Tahun 2000 tentang Kepelautan, belum sepenuhnya dapat dilaksanakan. Masih banyak pelaut Indonesia yang menerima perlakuan yang tidak sesuai dengan kesepakatan kerja yang diperjanjikan.

Pemutusan Hubungan Kerja (PHK) sepihak yang dilakukan oleh pengusaha kapal, masih sering terjadi. Kasus-kasus PHK sepihak ini terkadang tidak didasarkan pada peraturan yang berlaku. Dalam kasus pemutusan hubungan kerja sepihak yang dilakukan oleh pengusaha kapal, terkadang tidak memperhatikan ketentuan-ketentuan dalam Pasal 418 KUHD, UUK dan UU No. 15 Tahun 2016 mengenai Ratifikasi MLC 2006 dan PP No. 7 Tahun 2000. Hak-hak pelaut atas PHK sepihak ini juga tidak semuanya diberikan oleh perusahaan, seperti hak atas uang ganti rugi akibat PHK sepihak sesuai dengan kontrak kerja yang diperjanjikan, hak biaya pemulangan, dan hak atas jaminan dan kesejahteraan. Kasus AFSP dengan Nomor Perkara 215/Pdt.SusPHI/2018/PN.Jkt.Pst, adalah salah satu contoh bahwa dari adanya tindakan kesewenang-wenangan pengusaha kapal terhadap pelaut.

\section{DAFTAR PUSTAKA}

Abbas Salim, 2013, Manajemen Transportasi, PT. Raja Grafindo Persada, Jakarta.

Engkos Kosasih, dan Hananto Soewedo, 2007, Manajemen Perusahaan Pelayaran, (STMT) Trisakti, Jakarta.

Hadi Supriyono, 2015, Hukum Maritim, Semarang, Politeknik Ilmu Pelayaran Semarang.

International Maritime Organization (IMO) and International Labour
Organization (ILO), Maritime Labour

Convention 2006.

International Transport Workers Federation

(ITF), 2006, A Seafarers' Bill of

Rights, An ITF Guide for Seafarers to

the ILO Maritime Labour

Convention, 2006, The International

Transport Workers' Federation (ITF),

London, United Kingdom.

Irwansyah, 2020, Penelitian Hukum Pilihan

Metode \& Praktik Penulisan Artikel,

Buana Media, Yogyakarta.

Kitab Undang-Undang Hukum Dagang.

Lawrence M. Friedman, 1984, American

Law: An invalueable guide to the

many faces of the law, and how it

affects our daily lives, W.W. Norton

\& Company, New York.

Lexy J. Moleong, 2006, Metodologi Penelitian Kualitatif, PT. Remaja Rosdakarya, Bandung.

Manullang, M, 2001, Manajemen Sumber Daya Manusia, BPFE, Yogyakarta.

Peraturan Pemerintah Republik Indonesia

Nomor 7 Tahun 2000 tentang

Kepelautan.

Peter Mahmud Marzuki, 2013, Penelitian

Hukum, Kencana Penada Media Grup, Jakarta.

Putusan Pengadilan Negeri Jakarta Pusat Nomor 215/Pdt.Sus-PHI/2018/PN Jkt.Pst.

Sahya Anggara, 2018, Hukum Administrasi Negara, Pustaka Setia, Bandung.

Sedarmayanti \& Syarifudin Hidayat, 2002,

Metodologi Penelitian, CV. Mandar Maju, Bandung.

Setiono, 2004, Rule of Law (Supremasi Hukum), Magister Ilmu Hukum

Program Pascasarjana Universitas

Sebelas Maret, Surakarta.

Siswanto Sastrohadiwiryo, 2002,

Manajemen Tenaga Kerja Indonesia Pendekatan Administrasi dan Operasional, Bumi Aksara, Jakarta.

Soekanto, Soerjono, 2007, Pengantar Penelitian Hukum, UI Press, Jakarta.

Soerjono Soekanto \& Sri Mamudji, 2001, Penelitian Hukum Normatif (Suatu 
Tinjauan Singkat), Rajawali Pers, Undang-Undang Dasar Negara Republik Jakarta. Indonesia Tahun 1945.

Sudikno Mertokusumo, 2003, Penemuan Undang-Undang Republik Indonesia Hukum: Sebuah Pengantar, Liberty, Nomor 13 Tahun 2003 tentang edisi pertama, Yogyakarta.

Sukandarrumidi, 2006, Metodologi Ketenagakerjaan.

Penelitian Petunjuk Praktis Untuk Penelitian Pemula, Cetakan ke-3, Gadjah Mada University Press, Yogyakarta.

Undang-Undang Republik Indonesia Nomor 15 Tahun 2016 tentang pengesahan MLC 2006 sebagai Undang-Undang Maritim di Indonesia.

Suratman dan H. Philip Dillah, 2010, Metode Penelitian Hukum, Alfabeta, Bandung.

Umar Kasim, 2004, Hubungan Hukum dan Pemutusan Hubungan Kerja, Info Hukum Volume 2 ke VI 2004, Jakarta.

Undang-Undang Republik Indonesia Nomor 17 Tahun 2008 tentang Pelayaran.

Yasminingrum dan Edi Pranoto, 2014, Pengantar Hukum Administrasi Negara, Semarang, UNTAG Semarang. 